\title{
A REVIEW ON MANAGED AQUIFER RECHARGE BY CHECK DAMS: A CASE STUDY NEAR CHENNAI, INDIA
}

\author{
S. Parimala Renganayaki ${ }^{1}$, L. Elango ${ }^{2}$ \\ ${ }^{1}$ Research Scholar, ${ }^{2}$ Professor, Department of Geology, Anna University, Chennai-600 025, Tamil Nadu, India, \\ sunparimar@yahoo.co.in,elango@annauniv.edu
}

\begin{abstract}
Managed Aquifer Recharge (MAR) through check dams is the intentional recharge of water in the aquifers. The objective of this paper is to present a review of research work carried out on the impact of check dams in improving the groundwater quantity, quality and livelihood of people. Further, investigation carried out on the effectiveness of a check dam across Arani River, located north-west of Chennai, Tamil Nadu, India is also presented as a case study. The study reveals that proper maintenance of check dams will result in the sustainable replenishment of groundwater resources in a region. In general the MAR through check dam is found to be one of the efficient methods to improve the groundwater head and quality which in turn improve the livelihood of community as indicated by most of the studies. Case study carried out near Chennai is an evident that check dam has increased the groundwater level up to 1.5 $m$. Thus MAR by check dam can be considered as a best option for efficient and sustainable management of groundwater resources.
\end{abstract}

Index Terms: Water resources management, Groundwater recharge, Groundwater Quality, Socioeconomic impact, Chennai, Recharge structure

\section{INTRODUCTION}

Dependence on groundwater is ever increasing especially in regions where surface water resources are limited and rainfall is scarce or erratic. Over-exploitation of groundwater for various purposes results in rapid decline in groundwater table in several parts of the world. It is necessary to increase the rainfall recharge in such regions in order to balance the overdraft of groundwater. Human intervention can lead to increase in rainfall recharge, which will eventually improve groundwater storage and water quality. Gale et al. (2006) describes Managed Aquifer Recharge (MAR) as intentional storage and treatment of water in aquifers. Methods of MAR include aquifer storage and recovery (ASR), aquifer storage, transfer and recovery (ASTR), infiltration ponds, infiltration galleries, soil aquifer treatment, percolation tanks and check dams (Dillon et al. 2009). MAR can be used to address a wide range of water management issues which includes storing water in aquifers for future use, smoothing out supply and demand fluctuations as part of an integrated water management strategy, stabilizing or raising groundwater levels where over-exploited, reducing loss through evaporation and runoff, impeding storm runoff and soil erosion, maintaining environmental flows in streams and rivers, managing saline intrusion or land subsidence, disposal or reuse of waste and storm water (Gale et al. 2006). Implementation of MAR requires knowledge about the location, hydrogeology, quantity and quality of water to be recharged. MAR through check dams is generally considered as a suitable method to improve recharge in the unconfined aquifers. Check dams can hold sufficient water during monsoon season and building a series of check dams along a river is being practiced in several parts of the world including India (Agoramoorthy et al. 2008). Thorough review is essential on the research work that had been carried out on the impact of check dam as a method of MAR. This will help to understand the usefulness of check dams in different geological settings, its long term impact and methods of determining its efficacy. Hence, this study was carried out to review the impact of check dams as a method of MAR in improving the groundwater quantity, quality and livelihood, and also to present a case study from Chennai, Tamil Nadu, India.

\section{CHECK DAM FOR MAR}

Construction of check dams across rivers is one of the methods of MAR to impound the surface runoff so as to increase the groundwater recharge. In arid or semi arid regions such as southern part of India, the rivers flow only for a few days in a year (non perennial rivers) during the monsoon. Hence, large quantum of rainfall reaches the sea as runoff and also results in flooding during peak monsoonal rains. MAR by the check dams will help in harvesting this surface runoff, by increasing the contact time between the water and the river bed to facilitate infiltration. This improves the groundwater recharge and reduces the runoff into the sea. Groundwater quality is also expected to improve as long as the impounded water is safeguarded from contamination. Several researchers have carried out investigations on assessing the impact of check dam on groundwater potential. These studies can be 
broadly classified into the ones that looked into the increase in groundwater level, changes in groundwater quality and socio economic impacts of livelihoods. A brief review of these research studies are presented in the following sections.

\subsection{Study on increase in groundwater level}

Groundwater level data is a best indicator to understand improvement in groundwater recharge due to the construction of check dams. Various researchers have carried out studies on assessing the impact of check dams by the groundwater level measurements and these studies are summarized in Table- 1 .

A study on evaluation of recharge from check dam by groundwater table response was carried by Muralidharan (2007) in the granitic terrain of Hyderabad, India. In this study, a comparison is made between the percentage of natural rainfall recharge and percentage of artificial recharge due to check dam with respect to rainfall recharge using tritium technique. It was estimated, that natural rainfall recharge in granitic terrain varied from $5 \%$ to $8 \%$, whereas rainfall recharge through check dam varied from $27 \%$ to $40 \%$. This study shows that the natural recharge has increased between $22 \%$ and $32 \%$ due to the construction of check dam in the granitic terrain.

Palanisami et al. (2006) assessed the effect of artificial recharge by check dam in the hard rock region of Coimbatore, Tamil Nadu, India. Groundwater level fluctuation was monitored in the wells located at a distance from $64 \mathrm{~m}$ to 400 $\mathrm{m}$ from the check dam. The influence of check dam recharge was studied for a period of three months from the start of filling up of the check dam. Groundwater level rose to the maximum level in the wells located within $64 \mathrm{~m}$ in 48 days, but wells located at $400 \mathrm{~m}$ from the structure took 3 months to reach maximum water level. This study indicated greater impact of check dam in the case of wells located within $64 \mathrm{~m}$ from the check dam.

Gale (2006) carried out a study on check dams in three different hydro-meteorological and geological environments in the states of Gujarat (fractured granite rocks), Tamil Nadu (fractured charnockite rocks) and Maharashtra (Deccan basalt) in India. Natural recharge and additional recharge induced by the check dam was estimated by water budgeting. The estimated natural rainfall recharge in Gujarat varied from $7 \%$ to $27 \%$ whereas additional recharge of $4 \%$ to $16 \%$ was estimated due to the construction of check dam. Estimated natural rainfall recharge in Tamil Nadu and Maharashtra was $6 \%$ and $5 \%$ respectively. Additional recharge of $23 \%$ and 13\% was estimated in Tami Nadu and in Maharashtra respectively. It was also learned that irrespective of the geology there was a considerable amount of contribution to aquifer recharge due to the construction of check dam in these areas as the rocks are highly fractured and jointed.
A study was undertaken by Ashraf et al. (2007) to evaluate the impact of small dams on groundwater levels in the Ravalpindi division of Pakistan. Three check dams from the same area were selected for this study. Changes in water level of the wells located in the vicinity of the small dams were monitored before and after construction of the check dam. Depth to groundwater table before construction of dam in three sites varied from 9 to $25 \mathrm{~m}, 12$ to $45 \mathrm{~m}$ and 5 to $90 \mathrm{~m}$ below ground level. Whereas after the construction of check dam depth to the groundwater table varied from $6 \mathrm{~m}$ to $15 \mathrm{~m}, 7 \mathrm{~m}$ to $39 \mathrm{~m}$ and $2 \mathrm{~m}$ to $7 \mathrm{~m}$. Due to increased availability of groundwater, additional wells were constructed in this area and the number of wells increased from 135 to 500 .

Assessment of recharge from three proposed dams was carried out by Alderwish (2010) in Yemen. Two techniques, such as a simple water balance model and a more refined Darcian approach was adopted to predict expected recharge from three check dams and a gravity dam. The estimated recharge by these two models over the period from 2007 to 2026 was very close at three new dam sites. The total average induced recharge from the three check dams during 2007 to 2026 were $141,407 \mathrm{~m} 3$ which was higher than the average induced recharge of $103,853 \mathrm{~m} 3$ from a single gravity dam. The quantum of expected recharge from three check dams was greater than gravity dam. Alderwish (2010) also reported that the construction of gravity dam at a tributary was not suitable due to the relatively small predicted runoff. Instead, a series of three small check dams would be a best alternative to augment the groundwater potential in this area.

Augmentation of groundwater by check dam was carried out in Delhi, India by Saxena et al. (2010). Four check dams were constructed on rivulets and sixteen piezometers were established to monitor the impact of artificial recharge on groundwater regime. The groundwater level rose by $4 \mathrm{~m}$ due to the construction of this check dam. The efficiency of the check dam in this area was found to be $98 \%$. Check dam has also increased the vegetation, which in turn increased the biodiversity. 
Table- 1: Impact of check dam on groundwater level

\begin{tabular}{|c|c|c|}
\hline $\begin{array}{c}\text { Reference } \\
\text { (alphabetical } \\
\text { order) }\end{array}$ & Location & Findings \\
\hline $\begin{array}{l}\text { Alderwish } \\
(2010)\end{array}$ & $\begin{array}{l}\text { Sana Basin, } \\
\text { Yemen. }\end{array}$ & $\begin{array}{l}\text { Increase in recharge by } \\
\text { about } 36 \%\end{array}$ \\
\hline $\begin{array}{l}\text { AI-Muttair et } \\
\text { al. (1994) }\end{array}$ & $\begin{array}{l}\text { Malham, Al- } \\
\text { Amalih } \\
\text { Saudi Arabia. }\end{array}$ & $\begin{array}{l}\text { Suggested to gradually } \\
\text { release water in to } \\
\text { downstream for } \\
\text { improving recharge. }\end{array}$ \\
\hline $\begin{array}{l}\text { Ashraf et al. } \\
(2007)\end{array}$ & Pakistan. & $\begin{array}{l}\text { Groundwater level was } \\
\text { increased from } 3 \text { to } 5 \\
\text { m. }\end{array}$ \\
\hline $\begin{array}{l}\text { Al-Turbak } \\
\text { (1991) }\end{array}$ & $\begin{array}{l}\text { Al-Amalih, Saudi } \\
\text { Arabia. }\end{array}$ & $\begin{array}{l}\text { Sedimentation reduces } \\
\text { the efficiency of the } \\
\text { check dam. }\end{array}$ \\
\hline $\begin{array}{l}\text { Gale et al. } \\
(2006)\end{array}$ & Satlasana, India. & $\begin{array}{l}\text { Recharge increased } \\
\text { from } 6 \% \text { to } 24 \%\end{array}$ \\
\hline Gale (2006) & $\begin{array}{l}\text { Gujrat, Tamil } \\
\text { Nadu, Maharastra, } \\
\text { India. }\end{array}$ & $\begin{array}{l}\text { Considerable } \\
\text { contribution to aquifer } \\
\text { recharge }\end{array}$ \\
\hline $\begin{array}{l}\text { Mudrakartha } \\
\text { (2003) }\end{array}$ & Gujarat, India. & $\begin{array}{l}\text { Suggested to increase } \\
\text { number of wells near to } \\
\text { the structure to get } \\
\text { maximum benefit. }\end{array}$ \\
\hline $\begin{array}{l}\text { Muralidharan } \\
\text { (2007) }\end{array}$ & $\begin{array}{l}\text { Andhra Pradesh, } \\
\text { India. }\end{array}$ & $\begin{array}{l}\text { Recharge increased } \\
\text { from } 27 \% \text { to } 40 \% .\end{array}$ \\
\hline $\begin{array}{l}\text { Neumann et al. } \\
\text { (2004) }\end{array}$ & $\begin{array}{l}\text { Tamil Nadu } \\
\text { India. }\end{array}$ & $\begin{array}{l}33 \% \text { of additional } \\
\text { water could be } \\
\text { extracted from the } \\
\text { wells located nearer to } \\
\text { the check dam. }\end{array}$ \\
\hline $\begin{array}{l}\text { Niranjan and } \\
\text { Srinivasu } \\
\text { (2012) }\end{array}$ & $\begin{array}{l}\text { Saurashtra, } \\
\text { Gujarat,India. }\end{array}$ & $\begin{array}{l}\text { Groundwater level near } \\
\text { the check dam was } \\
\text { increased about } 2 \mathrm{~m} \text {. }\end{array}$ \\
\hline $\begin{array}{l}\text { Palanisami et } \\
\text { al. (2006) }\end{array}$ & $\begin{array}{l}\text { Tamil Nadu, } \\
\text { India. }\end{array}$ & $\begin{array}{l}\text { Impact of check dam } \\
\text { on water quantity was } \\
\text { identified }\end{array}$ \\
\hline $\begin{array}{l}\text { Pandey et al. } \\
\text { (2004) }\end{array}$ & $\begin{array}{l}\text { Rozam, } \\
\text { Gujarat,India. }\end{array}$ & $\begin{array}{l}\text { Well yield has } \\
\text { increased from } 0.64 \\
\text { litre per second to } 1.50 \\
\text { litre per second after } \\
\text { the intervention } \\
\text { structure. }\end{array}$ \\
\hline $\begin{array}{l}\text { Saxena et al. } \\
\text { (2010) }\end{array}$ & $\begin{array}{l}\text { New Delhi, } \\
\text { India. }\end{array}$ & $\begin{array}{l}\text { Rise of groundwater } \\
\text { level up to } 4 \mathrm{~m} \text {. }\end{array}$ \\
\hline
\end{tabular}

Mudrakartha (2003) carried out a study on augmentation of groundwater resources by a check dam at Gujarat state, India. In this study the wells located within $500 \mathrm{~m}$ from the structure were monitored by installing automatic water level indicators. The wells which were located far away from the structure required more time to get the maximum benefit from the structure. Hence, it was suggested to increase the number of wells near to the structure in order to get the maximum benefit.

Technical effectiveness of a check dam at Tamil Nadu state, India was carried by numerical approach (Neumann et al. 2004). Natural recharge and induced recharge by the check dam was estimated using water balance study. MODFLOW software was used to simulate the effect of the check dam. Tube wells were placed in the model at various locations from the centre of the check dam. The numerical model was used to calculate the volume of water removed from the aquifer through the tube wells. These were compared with the total volume recharged. This study showed that $33 \%$ of recharged groundwater was abstracted from the wells located at a distance of $110 \mathrm{~m}$ from the recharge structure. The abstracted volume decreased from $33 \%$ to $4 \%$ if the wells are located far away $(510 \mathrm{~m})$ from the recharge structure. Palanisami et al. (2006) and Mudrakartha (2003) have also made similar observations.

An assessment of MAR and its effectiveness in watershed management were studied by Gale et al. (2006). This study was carried out in the gneiss and charnockite rocks of Tamil Nadu, India. The wells located within the vicinity of main structure showed the maximum water level fluctuation due to the recharge. The natural groundwater recharge was estimated to be around $6 \%$ of the rainfall, and they reported that the structure was providing an additional recharge of $23 \%$ over the natural groundwater recharge.

Effectiveness of recharge of groundwater by a check dam was assessed by Al-Turbak (1991) in Saudi Arabia. Three wells in downstream and one well in upstream of the structure were used to monitor the groundwater level fluctuations. Infiltration test were conducted to quantity the water infiltrated into the aquifer on the downstream side. Infiltration from reservoirs increases sharply just after a flood event, then they had observed drop in the infiltration rate after some time due to sedimentation. Al-Turbak (1991) observed that due to sedimentation the efficiency of the check dam has reduced. The study suggests that release of water from the check dam on the channel on downstream will be a feasible alternative to increase the groundwater recharge if the precipitation is higher than the average.

A study was conducted by Al-Muttair et al. (1994) with the aim of improving the efficiency of recharge by check dams. Five alternative management plans were applied at the check dams located in central Saudi Arabia. The first management plan was not releasing the water from the check dam, second alternative was releasing the reservoir water to downstream channel with long downstream channel and third plan was releasing the water to downstream basin with shorter downstream basin. Alternative 4 was removal of silt from the 
reservoir bed which was best suitable for recharge dams with a significant accumulation of silt. Fifth management alternative was scratching of the reservoir bed, was best suited if the surface of the reservoir is relatively large and the silt deposits are not too deep. After adopting each plan the rate of infiltration and recharge was estimated by Al-Muttair et al. (1994). The second alternative was considered to be attractive because of high infiltration capacity of natural river tributaries even under wet condition.

Impact of small water harvesting and artificial recharge interventions in Singoda river basin, coastal Saurashtra, India was made by Niranjan and Srinivasu (2012). They compared the pre-monsoon water levels of the wells located nearer to check dam and far away from the check dam. This study indicated that the average rise in groundwater levels in the wells near the check dams was $9.63 \mathrm{~m}$ as compared to those wells located away from the check dam (7.64 m). Further, the wells located within the influenced area yields 3 to 7.35 litre per second and water spread area in the basins increased by 3,024 hectares during monsoon season.

Pandey et al. (2004) assessed the influence of a check dam in Rozam, Gujarat, India by observing the groundwater levels in 50 open wells. They observed that the water table has gone up by $2.57 \mathrm{~m}$ in year 2002 and $2.10 \mathrm{~m}$ in year 2003 in 50 open wells. The well yield has increased from 0.64 litre per second to 1.50 litre per second in year 2002 and 1.72 litre per second in year 2003 after the programme intervention. The comparison of pre and post programme data indicates that the programme has resulted in increased productivity, improved income and better food availability.

These studies indicate that the recharge of water stored by check dams result in increase in groundwater level. It is better to locate the extraction wells at optimum distance from the check dam in order get the maximum benefit of recharge. Check dam can function more efficiently by periodical silt removal or discharging the water at intermittent intervals so as to increase the recharge on the downstream side.

\subsection{Study on changes in water quality}

Quality of water is as important as that of its quantity. Water in the check dam is primarily rainfall runoff drained from different land use of the catchment. Hence the recharge of this water may change the hydrochemical characteristics of the resident groundwater. This aspect has been studied by several researchers. Research works based on impact of check dam on surface and groundwater quality are summarized in Table- 2 .
Table- 2: Impact of check dam on groundwater quality

\begin{tabular}{|c|c|c|}
\hline $\begin{array}{l}\text { Reference } \\
\text { (alphabetical } \\
\text { order) }\end{array}$ & Location & Findings \\
\hline $\begin{array}{l}\text { Bhagavan } \\
\text { and Raghu } \\
(2005)\end{array}$ & $\begin{array}{l}\text { Andhra } \\
\text { Pradesh, } \\
\text { India. }\end{array}$ & $\begin{array}{l}\text { Fluoride concentration in } \\
\text { groundwater reduced. }\end{array}$ \\
\hline $\begin{array}{l}\text { Bijukumar } \\
\text { and } \\
\text { Abraham } \\
\text { (2009) }\end{array}$ & $\begin{array}{l}\text { Peringottu } \\
\text { kurissi, } \\
\text { India. }\end{array}$ & $\begin{array}{l}\text { High concentration of ions in } \\
\text { the upstream due to } \\
\text { impoundment of irrigation } \\
\text { return and using of water for } \\
\text { bathing and washing. }\end{array}$ \\
\hline $\begin{array}{l}\text { Gale et al. } \\
(2006)\end{array}$ & $\begin{array}{l}\text { Satlasana, } \\
\text { India. }\end{array}$ & $\begin{array}{l}\text { Improved groundwater } \\
\text { quality }\end{array}$ \\
\hline $\begin{array}{l}\text { Mudrakartha } \\
(2003)\end{array}$ & $\begin{array}{l}\text { Gujarat, } \\
\text { India. }\end{array}$ & $\begin{array}{l}\text { Reduction in salinity and } \\
\text { concentrations of arsenic, } \\
\text { fluoride and boron by } \\
\text { dilution due to increased } \\
\text { recharge. }\end{array}$ \\
\hline $\begin{array}{l}\text { Palanisami } \\
\text { et al. (2006) }\end{array}$ & $\begin{array}{l}\text { Tamil } \\
\text { Nadu, } \\
\text { India. }\end{array}$ & $\begin{array}{l}\text { Concentration of ions in } \\
\text { groundwater of wells located } \\
\text { nearer to the check dam } \\
\text { reduced. }\end{array}$ \\
\hline $\begin{array}{l}\text { Samarah et } \\
\text { al. (2009) }\end{array}$ & $\begin{array}{l}\text { Wadi feifa, } \\
\text { Jordan. }\end{array}$ & $\begin{array}{l}\text { Dilutions of ions were } \\
\text { noticed due to the recharge } \\
\text { caused by the check dam. }\end{array}$ \\
\hline
\end{tabular}

Utility of check dams for dilution of fluoride concentration in groundwater was assessed by Bhagavan and Raghu (2005) in Andhra Pradesh, India. Fluoride concentration in the groundwater was $1.6 \mathrm{ppm}$ to $3.5 \mathrm{ppm}$ which is beyond the permissible limit $(1.5 \mathrm{ppm})$ for using it as drinking water in this site. A check dam was constructed in the upstream part of the region with high fluoride groundwater. They have reported that after the construction of check dam the fluoride concentration was reduced to the amount $1.5 \mathrm{ppm}$ which is not harmful to human health.

Evaluation of quality of groundwater recharged by the check dam was made by Samarah et al. (2009) at Southern Jordan valley, Saudi Arabia. The concentrations of the samples at different periods indicated that there was an increase in total dissolved solids (TDS) in all the wells except the wells located nearer to the check dam. They have observed decrease in TDS due the dilution effect of recharge of water stored in the check dam. Hence, it is evident that check dam had resulted in the improvement on groundwater quality. 
Water quality estimation of groundwater recharged by check dam was carried out by Palanisami et al. (2006) in Coimbatore, Tamil Nadu, India. Water samples were collected and analysed from the wells located at different distances from the check dam. The wells located within $64 \mathrm{~m}$ from the check dam had concentration of ions lower that the wells located far away from the structure.

Groundwater quality was monitored in selected dug wells and bore wells located near the check dam at Gujarat, India by Mudrakartha (2003). It was indentified that the check dam had improved the groundwater quality and even reduced the concentrations of toxic ions such as arsenic, fluoride and boron due to the dilution.

These studies showed that recharge from the check dam has resulted in improvement in groundwater quality. However, a few researchers have also highlighted the constraints involved in using check dam for improving the water quality.

Impact of check dams on the groundwater quality of a tropical river in Kerala, India was studied by Bijukumar et al. (2009). Electrical conductivity, alkalinity, nitrite, sulphate and total suspended solids of surface water from both upstream and downstream areas did not vary much throughout the year whereas, phosphate, nitrate and total dissolved solids exhibited significant seasonal variations in the upstream area of the check dam. The high concentration of water in the upstream of check dam was due to the use of impounded water for washing, bathing coupled with leaching of nutrients from the nearby agricultural fields. This research indicated that, recharge of this water will affect the groundwater quality.

Groundwater level measured by Gale et al. (2006) indicated that water level raised only by a few centimetres due to a check dam in Tamil Nadu, India in a region comprise of gneissic and charnockite rocks. Due to the poor recharge from the check dam no significant improvement in groundwater quality was observed by them. In general, the research work carried out on the impact of check dam indicates decrease in concentration of ions in groundwater due to the recharge of relatively good quality water from the check dam. However, improvement in groundwater quality is dependent on the quality of water stored by the check dam. Hence, it is important to maintain the quality of water stored in the check dam by taking certain precautions like preventing discharge from the nearby agricultural lands, dumping of domestic wastes, release of sewage etc.

\subsection{Study on socio economic impact}

Managed aquifer recharge by check dams needs to be beneficial to local community and it has to improve the livelihood of the people. MAR will result in changes in quantity and quality of water, which in turn will have an impact on the people living in the nearby areas. The salient aspects of research work on the impact of check dam on livelihood are summarized in Table-3.

Participation of communities in building and managing temporary check dams in Kerala, India and its impact on community was assessed by Balooni et al. (2008). Secondary data such as background information on the study area were collected from government agencies and primary data were collected from farmers using a structured pre-tested questionnaire. The study found that, only because of check dam agricultural activity was possible during summer season. That is, the check dam has eventually increased the scope of growing cash crops even during summer period. So this was motivated the people in participation in the construction and management of temporary check dams. This research is an evidence of check-dam playing a vital role in sustaining and enhancing the agrarian life of this area.

Examination of impact of check dams on agricultural development and on farmers was carried out by Khlifi (2010) in Northwestern Tunisia. A socio-economic survey was carried out by questionnaire with the farmers living around the dams. The water conserved by the structure was used by the farmers to irrigate seasonal vegetable crops, fodder, and especially fruit tree plantations, indicating shifts in the farming systems. Sheep productivity was doubled as a consequence of better foddering due to availability of water. The average annual net income for the local community has doubled due to increased production of crops and livestock.

Evaluation of sociological impact of a check dam in Madhya Pradesh, India was carried out by Khosla (1999). Quantitative data related to check dam impact was gathered through household surveys using the pre tested questionnaires. The survey indicated that construction of check dam has increased water availability. People have built better homes due to increased income as sustained agriculture was made possible due to the check dam.

Most of the research work on check dam by Mudrakartha (2003), Palanisami et al. (2003), Gale et al. (2006), Neumann et al. (2004)) indicate positive impact on livelihood. The researchers who have used groundwater level measurements to evaluate the impact of check dams as explained in previous sections have also looked into its impact on the community. A set of questioners distributed to people living around the check dam helped them to determine that the check dam has increased crop production, yield of well for irrigation and livestock. All these had led to increase in the income of the farmers.

Check dam in gullies was considered to be the most effective measure to conserve soil and water in Chinese Loess Plateau. Research work carried out by Xiangzhou et al. (2002) indicate that farmland could yield $750 \mathrm{~kg}-1,500 \mathrm{~kg}$ of maize per hectare because of the fertile soil and abundant water near the 
check dam. Due to the increased agricultural practice near check dam, sustainable food supplies could be made which provided employment opportunities to the farmers.

Table- 3: Impact check dam on livelihood

\begin{tabular}{|c|c|c|}
\hline $\begin{array}{l}\text { Reference } \\
\text { (alphabetical } \\
\text { order) }\end{array}$ & Location & Findings \\
\hline $\begin{array}{l}\text { Ashraf et al. } \\
\text { (2007) }\end{array}$ & Pakistan. & $\begin{array}{l}\text { Inequitable } \\
\text { distribution of } \\
\text { available water }\end{array}$ \\
\hline $\begin{array}{l}\text { Balooni et } \\
\text { al.(2008) }\end{array}$ & Kerala, India. & $\begin{array}{l}\text { Increase in } \\
\text { agriculture } \\
\text { activity during } \\
\text { summer season. }\end{array}$ \\
\hline Khlifi (2010) & Jendouba, Tunisia. & $\begin{array}{l}\text { Farming } \\
\text { systems } \\
\text { improved. }\end{array}$ \\
\hline Khosla, (1999) & $\begin{array}{l}\text { Madhya Pradesh, } \\
\text { India. }\end{array}$ & $\begin{array}{l}\text { Increased } \\
\text { income due to } \\
\text { sustained } \\
\text { agriculture }\end{array}$ \\
\hline $\begin{array}{l}\text { Mudrakartha } \\
\text { (2003), } \\
\text { Palanisami et } \\
\text { al.(2003), Gale } \\
\text { et al. (2006), } \\
\text { Neumann et al } \\
\text { (2004) }\end{array}$ & $\begin{array}{l}\text { Gujarat, } \\
\text { Coimbatore, } \\
\text { Maharastra, India. }\end{array}$ & $\begin{array}{l}\text { Increased the } \\
\text { crop production, } \\
\text { well irrigation } \\
\text { and increase in } \\
\text { the number of } \\
\text { livestock. }\end{array}$ \\
\hline Redlich (2010) & $\begin{array}{l}\text { Madya Pradesh, } \\
\text { India. }\end{array}$ & $\begin{array}{l}\text { Assured water } \\
\text { supply for } \\
\text { forming. }\end{array}$ \\
\hline $\begin{array}{l}\text { Samwanshi et } \\
\text { al. (2006) }\end{array}$ & Maharastra, India. & $\begin{array}{l}\text { No longer } \\
\text { subject to } \\
\text { vagaries of } \\
\text { monsoon and } \\
\text { women not } \\
\text { spending their } \\
\text { time in fetching } \\
\text { water. }\end{array}$ \\
\hline $\begin{array}{l}\text { Xiangzhou et } \\
\text { al. (2002) }\end{array}$ & $\begin{array}{l}\text { Loess Plateau, } \\
\text { China. }\end{array}$ & $\begin{array}{l}\text { Food production } \\
\text { self supported. }\end{array}$ \\
\hline
\end{tabular}

Samwanshi et al. (2006) carried out a study in a check dam in Gudwanwadi, Maharastra, India. Rainwater harvested through this check dam improved the livelihood by providing sufficient water for the needs of domestic, irrigation and livestock. They also indicated that community around Gudwanwadi were no longer subjected to the vagaries of the monsoon. Further, they observed that women were not spending their time for fetching water from greater distance.
A research project was undertaken by Redlich (2010) in Nagda, Ujjain District, Madhya Pradesh, India to assess the socio economic impacts of check dam upon the lives of farmers around the structure. The farmers narrated that they could get additional earnings due to the check dam and they could reinvest the income back into the farming. This was possible due to assured water supply for irrigation which improving educational opportunities, health care treatment.

The pros and cons of impact of a check dam on livelihood were identified by Ashraf et al. (2007) in Pakistan. Illegal taping of water, non-functional water use associations, leakage, improper maintenance of structure, broken outlets, and poorly maintained field channels resulted in unequal utilisation of water in the check dam. Need for an integrated programme was emphasised for effective utilization of available water to get maximum benefit to the people.

Review of research on socio economic aspects conclude that water harvested by the check dams increase the income of livelihoods mainly due to sustained agriculture. Women were able to save time as the water is made available near to their home. The pros and cons of check dam impact on livelihood indicated that integrated programme was required to solve the problem of inequitable distribution of water among upstream and downstream users.

\section{CASE STUDY NEAR CHENNAI}

Chennai is the capital of Tamil Nadu and it is a fourth largest Metropolitan City in India where the water supply is met from surface and groundwater resources. Surface water supplies for Chennai city is met from three reservoirs namely, Poondi, Cholavaram \& Redhills and the groundwater supply is met from the well fields located in north and south of the coastal aquifers. In recent years, population of the Chennai city and the rural area surrounding the city have faced severe water shortages due to continuous extraction of groundwater for irrigation and domestic purposes. This has also leaded to seawater intrusion (Rao et al. 2004, Ganesan and Thayumanavan 2009). Hence, several check dams were constructed across rivers to improve the groundwater potential. A study is currently being carried out by the authors of this paper to understand the effectiveness of a check dam across Arani River in Thiruvallur district, Tamil Nadu located north-west of Chennai, India (Fig-1). Construction of this check dam of $260 \mathrm{~m}$ length with a crest height of $3.5 \mathrm{~m}$ was completed in July 2010. The highest elevation of this study area is $29 \mathrm{~m}$ with respect to Mean Sea Level (MSL) and the area is sloping gradually from west to east towards Bay of Bengal. The average annual rainfall is around $1200 \mathrm{~mm} ; 35 \%$ falling in the south west (June- September) monsoon and 60\% during the northeast (October-December) monsoon. As per United States Department of Agriculture classification, soil orders of this area are alfisols, inceptisols, vetisols. Agriculture is the major source of economy and rice is the major food crop in this area. 


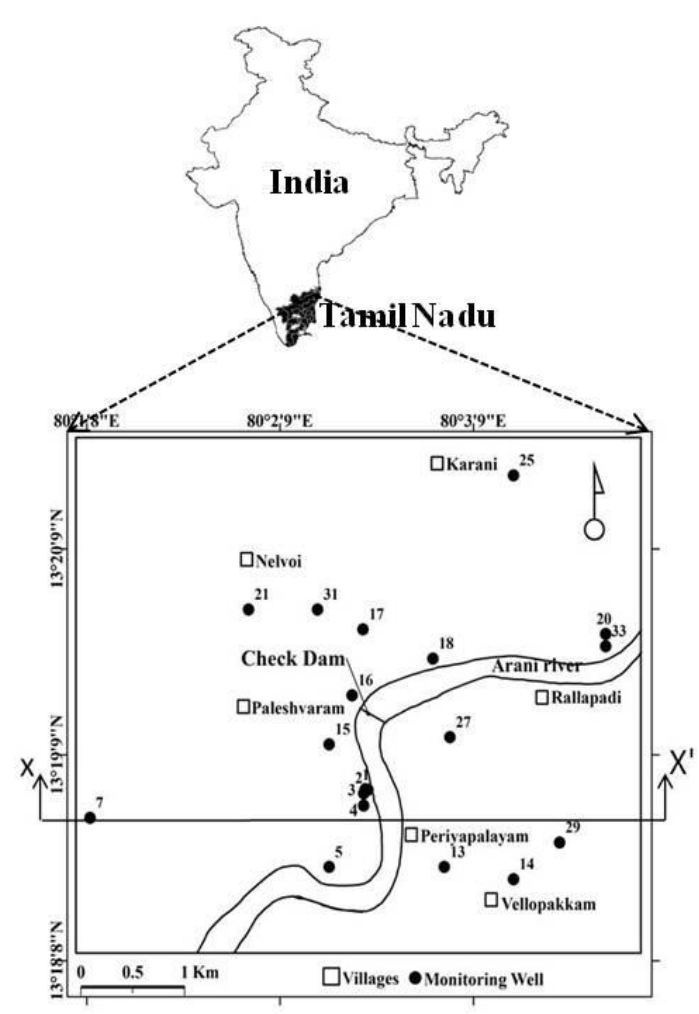

Fig-1: Map showing the study area with monitoring wells

\subsection{Increase in groundwater level before and after}

\section{construction of the check dam}

Nineteen monitoring wells were selected near the check dam and groundwater levels were measured periodically from July 2010 (before the construction of check dam) to July 2012. Groundwater level before and after the construction of check dam along west to east direction cross section $\left(\mathrm{X}-\mathrm{X}^{\prime}\right)$ is shown in Figure 2. This figure shows that before construction of check dam, the groundwater level was $15 \mathrm{~m}$ msl in July 2010, whereas after the construction of check dam, it was at $16.5 \mathrm{~m}$ and $17.8 \mathrm{~m} \mathrm{msl}$ in July 2011 and July 2012 respectively. That is the groundwater level increased by about $1.5 \mathrm{~m}$ in July 2011 and $2.8 \mathrm{~m}$ in July 2012. Thus considerable rise in water table was observed due the construction of check dam in this area.

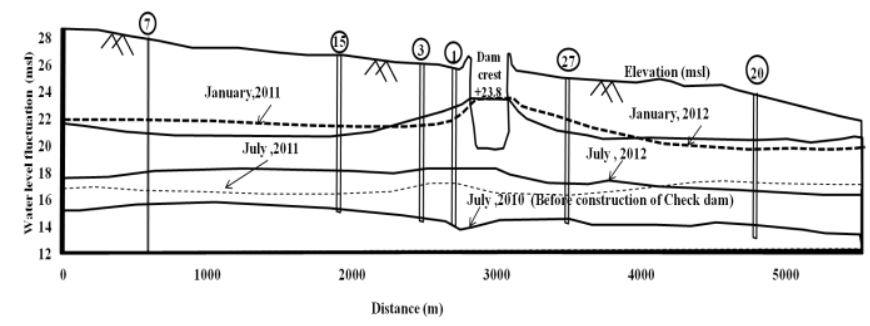

Fig - 2: Water level fluctuation before and after construction of

\section{CONCLUSIONS}

The review of research work on assessing the impact of check dam as a method of MAR on groundwater level, groundwater quality and socio economic aspects was carried out. It is from evident from all the studies that groundwater potential increase due to the construction of check dams. Efficiency of the check dam will be at its best by adopting proper maintenance activities such as silt removal and bed scratching at periodical intervals. To overcome the problem of reduction of recharge due to silting, water from the check dam can be released at periodical intervals so as to increase the recharge through the downstream side. It is generally observed by many researchers that groundwater quality improves within the vicinity of the check dam. However, the aerial extent of influence of check dam varies depending on the geology, hydrogeology as well as the storage capacity. However, improvement in groundwater quality depends on the quality of water stored by the check dam. It is important to maintain the quality of water by taking suitable precautions like preventing discharge from the nearby agricultural lands, release of domestic wastes, sewage, dumping of wastes etc. Water harvested by the check dam increase the income of livelihoods mainly due to sustained agriculture and increased availability of water for various uses. Case study in north of Chennai also signify increase in groundwater level by about $1.5 \mathrm{~m}$ after construction of the check dam. It is concluded that MAR through check dam is found to be one of the efficient method to improve the groundwater head, and quality which in turn improve the livelihood of community as indicated by most of the studies. Thus for efficient and sustainable management of water resources, MAR by check dam can be considered as a best option.

\section{ACKNOWLEDGEMENTS}

The authors thank the Department of Science and Technology, New Delhi, India for funding this research under the Women Scientist Scheme (Grant SR/WOS-A/ET-49/2010(G)).

\section{REFERENCES:}

[1]. Agoramoorthy G, and Chaudhary S, and Hsu, MJ (2008) The Check-Dam Route to Mitigate India's Water Shortages, Nat Resour J, 48:565- 583. 
[2]. Alderwish AM (2010) Induced recharge at new dam sites- Sana'a Basin, Yemen. Arab J. of geosci, 3: 283-293.

[3]. Al-Muttair FF, A1-Turbak, AS, and Sendil U (1994) Management of Recharge Dams in Saudi Arabia. J. of Water Resour Plan Manag, 120(6).

[4]. Al-turbak AS (1991) Effectiveness of recharge from a surface reservoir to an underlying unconfined aquifer. Hydrology of Natural and Manmade Lakes proceedings of the Vienna Symposium. IAHS Publ.no 206.

http://iahs.info/redbooks/a206/iahs 206 0191.pdf

[5]. Ashraf M, Kahlown, MA and Ashfaq A (2007) Impact of small dams on agriculture and groundwater development: A case study from Pakistan. Agric Water Manag 92(1-2):90-98.

[6]. Balooni K, Kalro AH and Kamalamma AG (2008) Community Initiatives In Building And Management Temporary Check-Dams Across Seasonal Streams For Water Harvesting In South India. Agric water manag, 2641-9.

[7]. Bhagavan S, Raghu V (2005) Utility of check dams in dilution of fluoride concentration in groundwater and the resultant analysis of blood serum and urine of villagers, anantapur district, Aandra Pradesh, India. Environ Geochem and Health, 27(1).

[8]. Bijukumar A, and Abraham KM (2009) Impact of Peringottukurissi Check Dam on Hydrography of Bharatapuzha River, Kerala. J of Inland Fisheries Soc, India,41(1).

[9]. Dillon P, Pavelic P, Page D, Beringen H, and Ward J (2009). Managed aquifer recharge: An Introduction. Waterlines Rep No. 13.National water commission.

[10]. Gale, IN, Macdonald, DMJ, Calow RC, Moench, M, Kulkarni, H, Mudrakartha, S, and Palanisami, K (2006) Managed aquifer recharge: An assessment of its role and effectiveness in watershed Management. Rep. No.CR/06/107N.(BGS)

http://nora.nerc.ac.uk/7453/1/CR06107N.pdf.

[11]. Gale IN (2006) Managed Aquifer Recharge: Lessons Learned From The Agrar Study

http://www.sahra.arizona.edu/unesco/allepo/Gale.pdf.

[12]. Ganesan M and Thayumanavan S (2009) Management strategies for seawater intruded aquifer system, J of Sustain Dev, 2(1) 94-106.

[13]. Khlifi S, Ameur M, Mtimet N, Ghazouani N, and Belhad $\mathrm{N}$ (2010) Impacts of small hill dams on agricultural development of hilly land in the Jendouba region of northwestern Tunisia. Agric Water Manag, 97(1), 50-56.

[14]. Khosla A (1999) Development alternatives. Check dam evaluation study. www.dainet.org/livelihoods/checkdams.htm.

[15]. Mudrakartha S (2003) Augmenting groundwater resources by artificial recharge at Aravalli Hills. Gujarat,India. http://www.iah.org/recharge/downloads/VIKSAT_INCEPTIO N REPORT12 May 04.pdf

[17]. Muralidharan D (2007) Evaluation of Check-Dam recharge through water-table response in ponding Area. Curr Sci, 92(10).

[18]. Neumann I, Barker J, and MacDonald D, Gale I (2004) Numerical approaches for approximating technical effectiveness of artificial recharge structures. Report Number. CR/04/265N, BGS.

www.iah.0rg/rechargedownloads/CR04265 Numerical modelling.

[19]. Niranjan V, Srinivasu VK (2012) Small water harvesting and artificial recharge interventions in Singoda river basin, coastal Saurashtra: Hydrological and Socio-economic impacts, Report - Institute for Resource Analysis and Policy, Hyderabad.

[20]. Palanisami K, Raviraj A, and Thirumurthi S (2006) Artificial Recharge in Hard Rock Areas of Coimbatore District -A Case Study. International conference on Groundwater sustainable Development problems, perspectives and challenges (IGC-2006)

http://jnuenvis.nic.in/publication/IGC\%202006\%20Abstracts. pdf.

[21]. Pandey R, Gupta A, and Chaudhary S (2004) Influence of surface water harvesting on ground water regime - a case of village Rozam, 30th WEDC International Conference, Vientiane, Lao PDR.

[22]. Redlich C (2010) Check dam impact assessment, Report by Action for Social advancement (ASA), http://www. asaindia.org

[23]. Rao S V N, Saheb S M, Ramasastri K S (2004) Aquifer restoration from seawater intrusion: A field-scale study of Minjur aquifer system - north of Chennai, Tamil Nadu, India. 18th Salt Water Intrusion Meeting. 18 SWIM, Cartagena (Spain) 31-May to 3-June.

[24]. Samarah M, Momani MA, Any RT, Jiries A, Naqa AL (2009) Evaluation of water quality of groundwater recharge In Wadi Feifa, Southern Jordan Valley. 13thInternational Water Technology Conference, IWTC 13, 2009, Hueghada,Egypt. http://www.iwtc.info/2009 pdf/13-6.pdf.

[25]. Saxena P,Chandra A,Garg, A,Sharma G, and Varma P (2010) Conservation of groundwater by artificial recharge in Delhi and Haryana State of India-A review. Int. J. App. Bio. Pharmaceutical Tech.1 (3), 989-993.

[26]. Somwanshi S, Dash P, and Prashant DP (2006) SocioEconomic Survey of Gudwanwadi Checkdam Project, Centre for Technology Alternatives for Rural Areas Department of Humanities and Social Sciences Indian Institute of Technology, Bombay.

[27]. Xiangzhou X, Hongwu Z, Shunxin F, Zhandi D, and Gan Zhiguo (2002) Check-Dam System in Gullies The Most Effective Measure to Conserve Soil and Water in Chinese Loess Plateau, 12th ISCO conference,Beijing,2002. http://www.tucson.ars.ag.gov/isco/isco12/VolumeIII/CheckDam System in Gullies.pdf. 